\title{
The phenomenon of fatherhood: cultural and philosophical approach
}

\author{
Amirzhuzhayev Shukurjon Kurbonovich ${ }^{1}$ \\ ${ }^{I}$ Senior Lecturer of the Department "National Idea; foundations of spirituality legal education" \\ Andijan State University, Republic of Uzbekistam
}

Email: shukurjona@adu.uz

\begin{abstract}
The article provides information about the place of the phenomenon of "fatherhood" in public life. The article also considers fatherhood as a special status that dominates the formation of a child's personality, its social role and factor influencing the formation of personal qualities brought up in a family.
\end{abstract}

Keywords: fatherhood, family relations, biological fatherhood, the institution of the family, problems of fatherhood, social status of becoming a man in the role of father.

\section{INTRODUCTION}

Interest in issues of love, marriage, family is great at any age, does not depend on gender and political preferences. Who will dispute the statement that "personal life" is an intimate, family, kindred life, without which human destiny is unthinkable, and the first lessons of which we acquire precisely in the family. The processes taking place today in this most important institution, according to some authors, are catastrophic, destructive; others tend to claim that we are contemporaries of family restructuring (albeit painful), which in itself is a creative process.

Today, most researchers of the phenomenon of "paternity", such as: O. G. Kalina and A. B. Kholmogorova and others agree that the role of the father is dominant in the formation of the personality of the child. At the same time, in domestic science the phenomenon of "fatherhood" has not been sufficiently studied in domestic science and is considered as a special status, social role, factor affecting the change in the personal qualities of men.

In the course of the theoretical analysis of various dictionary and encyclopedic publications, we found that the term "fatherhood" has a different interpretation. For example, in the dictionary of financial terms "Paternity - the fact of the origin of the child from this man; legally certified by the registry office of birth. " In a large legal dictionary, paternity is regarded as - the fact of the biological and (or) social origin of the child from a particular man. It is certified in the registry office by a birth record."

\section{METHODOLOGY}

In a large legal dictionary, "fatherhood" is interpreted as "the fact of the biological and (or) social origin of the child from a particular man"

In special dictionaries, you can find specific meanings of the term "paternity", which are used in specific areas of knowledge. In the encyclopedia of sociology, "fatherhood" is understood as the rights and obligations of a man in relation to a child arising from blood or legal relationship.

In the scientific definitions of "paternity," the criterion of consanguinity dominates. So, the researcher of family psychology, Yu.V. Borisenko believes that "paternity" is manifested through the personal and semantic sphere of a man, complementing the specific male functions realized in the family. In sociological research, "fatherhood" is often seen as a sociocultural phenomenon. Many authors believe that the change in the role functions of "fatherhood" depends on the specifics of the functioning of the family structure. In detail discuss on this topic in their research "Man in a changing world" I.S. Kon and 
A.V. Levchenko in their dissertation research "Representations of Men's Own Paternity and the Factors that Determine Them".

Foreign studies of "fatherhood" are focused on the analysis of this phenomenon in the following main areas:

1. The behavior of men in the framework of the paternal role;

2. The specificity of paternity in a divorce situation;

3. The institution of fatherhood in the context of family policy;

4. Paternal communities as a factor in the active involvement of men in educational activities;

5. Analysis of the social, cultural and historical determinants of paternity, etc.

In the domestic philosophical and sociological sciences over the past decade, a number of studies of the influence of the father on the development of the child have been conducted, these studies are reduced to the following spectrum:

- paternity as a conditioning element in the development of a child's personality;

- fatherhood as a factor in male identity;

- paternity as a determining component of the child's mental development.

In the works of R.V. Ovcharova, the idea of "fatherhood" is investigated, depending on various conditions and factors, the issues of men's psychological readiness for "fatherhood" are examined. In the studies of Yu.V. Borisenko, the phenomenon of "fatherhood" is described from the standpoint of the maturity of the personality of the father, his influence on the development of the personality of men. By T.V. Separate aspects of "fatherhood" are subjected to arkhipovy research, namely motivation to become a father, psychological readiness for fatherhood, modern stereotypes of this phenomenon. The issues of the father's influence on the child's intellectual, moral and moral development, his sexual identification, self-esteem, volitional sphere, as well as on the sphere of family relations are considered in the works of O.G. Kalina, G. B. Shaumarova, R. S. Samarova and others.

As part of a sociological approach to the study of the phenomenon of "fatherhood," I.S. Kon in his work "Fatherhood as a social institution" analyzes its relationship with other social institutions, as well as the process of inclusion of the father's activity in preserving and transmitting sociocultural experience to future generations. In addition to the work of I.S. Kohn, this analysis can be traced in the works of several other authors and others.

\section{ANALYSES}

Domestic sociological, pedagogical, psychological studies of the phenomenon of "fatherhood" began to develop actively only in the last decade, the author E.A. Chikalova proposes the following differentiation of modern domestic studies of the phenomenon of "fatherhood":

$\circ$ analysis of foreign studies of paternity;

o study of the influence of personality factors on the personality of the child;

$\circ$ a study of the influence of fatherhood on the development of the personality of the man himself;

o the study of the role of the father in the structure of self-identity, in the mass consciousness;

o analysis of the processes of transformation of "fatherhood" in modern social conditions;

o typology of "fatherhood".

Modern scientific trends in Russian studies of the phenomenon of "fatherhood" distinguish it in an independent direction and cover its practical aspects, etc. Structural models and stages of fatherhood formation are examined in detail in the works of a number of authors, revealing the essential characteristics of the concepts of "paternal attitude", "productive paternal attitude", their content and criteria, etc. In their studies, most scientists agree that the feeling of "fatherhood" arises later than "motherhood". This is true not only for biological paternity, but also for social when it comes to the manifestation of parental functions in relation to adopted children. I.S. Cohn argued that it was the appearance of a child in the family and the building of constructive interpersonal relationships with him that increased the level of socialization and self-development of men. But the author also notes that a man needs time to comprehend the situation and feel himself in the new role of his father, accept his new feelings and learn to control them. This scientist identified four approaches to understanding the essence of the phenomenon of "fatherhood" or "fatherhood" as a fact of the child's origin from a particular man;

- analysis of the phenomenon of "fatherhood" as a social institution; 
- "fatherhood" as a component of male identity;

- the phenomenon of "fatherhood" as a practical activity in the upbringing and care of a child.

It is the fourth approach highlighted by I.S. Kon that is of current interest for our study, since it considers "fatherhood" as an awareness of parenthood, the adoption of a father's role by a man, and a feature of child-parent relations.

The modern crisis of the institution of the family in developed countries affects "paternity" rather than "motherhood", as a number of authors point out in their works. K.N Belogay considers the gender aspect of modern birth. As noted in her studies, women relate love, caring, affection, warmth, etc. to their priority functions. Fathers consider it their duty to provide knowledge, moral education, protection, to form a strong character with them, to teach them to survive in difficult conditions, to build your future, make money.

U.S. Sevastyanova in her study: "Psychological and acmeological factors in the development of a productive paternal relationship", in the structure of the father's parental activity, identifies the following criteria for a productive paternal attitude: parenting and paternity motives, the sequence of applied influences, emotional connection, emotional involvement, interaction style, a way to resolve problem situations, social control, accessibility, responsibility. Her studies showed that the attitude towards himself and the child develops and develops in a man under the influence of two groups of factors - personal (internal system of motives for personal relationships) and family (circumstances of the child's joining the family (birth, adoption), the nature of marital relations in the family).

Yu.V. Borisenko in his work "Fatherhood as a factor in the development of personality" identifies four groups of factors that influence the formation of the paternal role in the family:

1) relationship with the spouse;

2) the influence of the mother of the child on the formation of a man in the role of father;

3) environmental factors;

4) the personality of the child (gender, age, personality characteristics).

I.V. Pavlov detailed three groups of motives for fatherhood:

1. Economic motives when the birth or adoption of a child becomes economically beneficial for the family as a whole and the father in particular.

2. Social motives due to the desire to confirm their social status, male fullness and reproductive ability.

3. Psychological motives when men "have" children for self-realization. Such fathers expect their children to fulfill their dreams, to solve certain problems.

\section{DISCUSSIONS}

Another typology of paternity motivation proposed by the author T.V. Arkhipova, who identified three types of motivation for paternity, each of which includes a number of correlating motives:

1. Immature motives for the implementation of parenthood, but promising for further development: "an unaccountable desire to have a child", "a suitable age", "an understanding that children strengthen their families".

2. Missing motives due to the unplanned appearance of the child, paternity is a necessary circumstance and, as a result, lack of motivation to exercise parental functions.

3. Conscious motives such as "love for children", "desire to have a child from a loved one", "understanding that the child is the continuer of the family", which are an end in itself, and not a means of satisfying other needs.

\section{CONCLUSIONS}

Thus, a theoretical analysis of the phenomenon of "fatherhood" in foreign and domestic studies has shown that at the present stage of studying the institution of the family, the problem of "motherhood" is sufficiently developed, studied and presented in the writings of scientists, and the problems of "fatherhood" are much less frequently studied in scientific circles and is currently at the stage of theoretical understanding. 


\section{REFERENCES}

1. Akimova M.K., Ustseva M.N. The influence of the father and his image on the occurrence of addiction in adolescents // Higher Education Today. - 2010. - No. 5. - S. 63-67.

2. Arkhipova T.V. Parenthood in a gender perspective // Gender Psychology: Workshop / Ed. I.S. Klecin. - 2nd ed. - St. Petersburg: Peter, 2009 .-- S. 121-147.

3. Belogay KN, Alferova Yu.S. The formation of ideas about paternity in early adulthood // Bulletin of the Kemerovo State University. 2007. - No. 1. - S. 38-41.

4. Burlingame D. Pre-Oedipus relations between father and child // Journal of Practical Psychology and Psychoanalysis. 2002. - No. 2.

5. Large legal dictionary / A.Ya. Sukharev, V.E. Krutskikh, A.Ya. Sukharev. - M .: Infra-M, 2003. - P.409.

6. Borisenko Yu.V. The specifics of psychological assistance to the family in the context of work with fatherhood // Bulletin of the Kemerovo State University. - 2010. - No. 3. - S. 32-37.

7. Gritsanov A.A., Abushenko, V.L., Evelkin, G.M., Sokolova, G.N., Tereshchenko, O.V. Sociology: Encyclopedia. - http://voluntary.ru/dictionary/568

8. Kalina O.G., Kholmogorova, A.B. The role of the father in the mental development of the child. - M.: "Forum", 2011. - 112 p.

9. Kletsina I.S. Paternity in analytical approaches to the study of masculinity // Woman in Russian society. 2009. - No. 3 (52). - S. 29-41.

10. Kon I.S. A man in a changing world. - M.: Time, 2009 .-- 496 p.

11. Kon I.S. Fatherhood as a sociocultural institution // Pedagogy. - 2005. - No. 9. - page 3-16.

12. Lavrentieva Z.I. Foster family as a socio-pedagogical phenomenon: monograph. - Novosibirsk: Publishing House of NGPU, 2014 .-- 218 p.

13. Levchenko A.V. Ideas of own fatherhood in men and the factors that determine them // Abstract. diss. ... cand. psychol. sciences / A.V. Levchenko. - Krasnodar, 2009 .-- 28 p.

14. Maltseva, D.V. Theoretical approaches to the study of fatherhood in modern Western sociology / D.V. Maltseva // Monitoring of public opinion. - 2010. - No. 5. - Issue. 99. - S. 272-289.

15. Ovcharova R.V. Tokareva Yu.A. Standardization of the research methodology of the motivationneed sphere of fatherhood // News of the Ural State University. Ser. 1. Problems of education, science and culture. - 2010. - No. 3. - T. 78. - S. 75-82.

16. Pavlov I.V. The psychology of fatherhood: a review of research and some conclusions about the current state of the problem // Perinatal psychology and psychology of parenthood. 2008. - No. 4. - S. 78-95.

17. Protopopov S.S. Theoretical foundations of the study of the phenomenon of fatherhood // Cultural Studies. - 2009. - No. 12. - S. 46-49.

18. Salimov Yu.F. Uzbekiston Mustailligi Sharoitida Tarbiani Milliy Khususiyatlari (sociologist talil) // Sociology of Fanlari Nomzodia Ilmiy Darazhasini Olish Uchun Yezilgan Abstract. Toshkent, 2016 .-- 23 b.

19. Sevastyanova U.Yu. Psychological and acmeological factors in the development of a productive paternal relationship // Abstract. diss. ... cand. psychol. sciences. - Kostroma, 2015 .-- 27 p.

20. Dictionary of financial terms / A.V. Sharkova, A.A. Kilyachkov. - M .: Publishing house "Dashkov and K", 2015.

21. Smarov R.S. Ways to improve marriage and family relations // J. Economics and statistics. No. 4, 1998.

22. Tokareva Yu.A. Psychological foundations of the educational activity of the father // Abstract. diss. Dr. Psychol. sciences. - Yekaterinburg, 2012 .-- 48 p.

23. Filippova G.G. The psychology of motherhood. - M.: Publishing House of the Institute of Psychotherapy, 2002. - $240 \mathrm{p}$.

24. Chikalova EA Social notions of paternity and the norms of masculinity in young men // Abstract. diss. ... cand. psychol. sciences., 2014 .-- 208 p.

25. ShoumarovF. B., Shoumarov Sh. B. Family and love. - T .: Ibn Sino, 1994.- 120 p.

26. Coltrane S. Fathering: Paradoxes, Contradictions, and Dilemmas / S. Coltrane / Men's Lives / By Michael Kimmel. - 8th edition. - Boston, 2009. - page. 432-449. 
27. Doucet A. Do Men Mother? Fatherhood, Care and Domestic Responsi-bility. - Toronto: University of Toronto Press, 2006 .-- 350 p., Wolde A. VaterimAufbruch. Deutungsmuster von Vaterlichkeit und Mannlichkeitim Kontext von Vaterinitiativen / A. Wolde. - Wiesbaden: VS Verlag fur Sozialwissenschaften, 2007 .-- 311 page.

28. Lewis J. The problems of fathers: Policy and behavior in Britain / J. Lew-is / Making Men into Fathers: Men, Masculinities and the Social Politics of Father-hood / Ed. by B. Hobson. Cambridge, 2002. - Pp. 125-149.

29. Marsiglio W. Exploring Fatherhood Diversity / W. Marsiglio, R.D. Day, M.E. Lamb // Marriage \& Family Review. - 2000 - No. 4. - Vol. 29. - Pp. 269-293.

30. Wolde A. VaterimAufbruch. Deutungsmuster von Vaterlichkeit und Mannlichkeitim Kontext von Vaterinitiativen / A. Wolde. - Wiesbaden: VS Verlag fur Sozialwissenschaften, 2007 .-- 311 p. 